\title{
Trace Metals in Water, Bottom Sediment, Shrimp and Dependent Human Blood in Ukwuani Local Government Area of Delta State, Nigeria
}

\author{
Patrick Omoregie Isibor $^{1^{*}}$ and Tunde Ohiokhioya Thadeus Imoobe ${ }^{2}$ \\ ${ }^{1}$ Department of Biological Sciences, Faculty of Science and Technology, Covenant University, Ota, \\ Ogun State, Nigeria. \\ ${ }^{2}$ Department of Animal and Environmental Biology, Faculty of Life Sciences, University of Benin, \\ Benin City, P.M.B.1154, Nigeria.
}

Authors' contributions

This work was carried out in collaboration between both authors. Author POI designed the study, performed the statistical analysis, wrote the manuscript and effected corrections from peer review. Author TOTI standardized the work scientifically, carried out the laboratory analysis and incorporated relevant literatures. Both authors read and approved the final manuscript.

Article Information

DOI: $10.9734 / A J E E / 2017 / 31978$

Editor(s):

(1) Wen-Cheng Liu, Department of Civil and Disaster Prevention Engineering, National United University, Taiwan and Deputy Director General, Taiwan Typhoon and Flood Research Institute, National United University, Taipei, Taiwan.

Reviewers:

(1) Isa Baba Koki, Northwest University Kano, Nigeria.

(2) Lorna T. Enerva, Polytechnic University of the Philippines, Philippines.

(3) Maria del Carmen Bermudez Almada, Ciencia de los Alimentos, Centro de Investigacion en Alimentacion y Desarrollo,

Complete Peer review History: http://www.sciencedomain.org/review-history/18663

Original Research Article

Received $1^{\text {st }}$ February 2017

Accepted 31 ${ }^{\text {st }}$ March 2017

Published $15^{\text {th }}$ April 2017

\section{ABSTRACT}

Trace metals (Fe, $\mathrm{Mn}, \mathrm{Zn}, \mathrm{Cu}, \mathrm{Pb}, \mathrm{Cd}$ and $\mathrm{Cr}$ ) levels were investigated in the water, bottom sediment, shrimp (Macrobrachium vollenhoveni) of Okumeshi River using Atomic Absorption Spectrophotometer (ASS); and blood of individuals that feed on the shrimps using an Inductively Coupled Plasma Mass Spectrometer (ICP-MS). The descriptive statistics such as the mean, range and standard error were for significant differences in the heavy metals, nutrients and total hydrocarbons in water and sediment samples was done using ANOVA $(P<0.05)$. Duncan Multiple Range (DMR) test was used to identify the source of variance using SPSS version 19.1.The order of accumulation in the matrices studied was bottom sediment $>$ shrimp $>$ water $>$ human blood. High level of zinc and copper in human blood can be attributed to their high concentrations in all 
environmental matrices. It can also be attributed to the high biological accumulation factors of the metals in the shrimp. Copper also has a high essentiality in the respiratory pigment haemocyanin of shrimps. These facts are buttressed by the significant correlations of copper and zinc concentrations in the shrimp with their concentrations in human blood. The observed insalubrity of the shrimps is a prognostic of chronic health hazards to the consumers; which is also a function of the predominant oil exploration activities. Copper had an uninterrupted transit into the blood of the consumers from the aqueous phase. While zinc showed some significant level of biomagnification. The study provided an early signal of likely impending catastrophe; necessitating a proactive regulation of trace metals released into the aquatic system through the prevalent anthropogenic activities; mainly oil exploration.

Keywords: Trace metals; water; sediment; sorption capacity; biological accumulation; Macrobrachium vollenhovenii.

\section{INTRODUCTION}

The study was conducted on Okumeshi River; within Uwuani Local Government area of Delta State. The river is a source of drinking water, finfish and shellfish to dwellers in near and far communities. Finfish and shellfish products from Okumeshi River serve as exotic local and foreign export products. However, despite its domestic, nutritional and economic values, the river is faced with incessant perturbations due to anthropogenic activities around it. The activities include oil exploration and exploitation, agricultural practices, discharge of domestic and industrial wastes, amidst others. Sadly, water and sediment matrices are receptors of these anthropogenic by-products; as well as they are habitats to aquatic organisms of high nutritional and economic values.

The indiscriminate dumping of refuse, discharge of industrial effluents, petroleum wastes and crude oil spills replete with heavy metals may culminate in serious health consequences on populace that consume the finfish and shellfish harvested from the river. The mechanism is by incorporation of the toxicants from anthropogenic perturbations such trace metals into the aquatic food; thereby biomagnifying up the pyramid of biomasses through alimentation [1-3]. Variability in water and sediment properties is a function of a number of factors which have been enormously reported in previous studies. Generally, these factors can be categorized as authoctonous and allothonous factors working in tandem. Tukura et al. [4] attributed variation of physico-chemical properties of water and sediment of Mada River, Nasarawa State, Nigeria to seasonal variation. The water matrix of an aquatic ecosystem is the first receptor of the contaminants released from anthropogenic activities. The sediment then serves as repository to the contaminants [5].
However, the rate of deposition of these contaminants is a function of their sorption capacities; which vary among contaminants. Ogbeibu et al. [6] observed that manganese, zinc, copper, cadmium, lead and total hydrocarbons had very high sorption capacities from water into the sediment of Ikpoba River. Furthermore, the contaminants journey from these environmental matrices into the tissues of biota where they are stored indefinitely. Froese et al. [7] reported bioaccumulation of polychlorinated biphenyls from sediments to aquatic insects in Saginaw Bay, Michigan, USA. Davies et al. [8] reported accumulation of heavy metals in tissues of Tympanotomus var radula from sediment of Elechi Creek, Nigeria. Akan et al. [9] attributed accumulation of metals in the gills, liver, stomach, kidney, bones and flesh tissues of Tilapia zilli, Clarias anguillaris, Synodentis budgetti and Oreochronmis niloticus from River Benue to the concentrations in the ambience. Isibor et al. [5] attributed impermissible levels of trace metals in Clarias gariepinus of Osse River, Edo State, Nigeria to high levels observed in the water and sediment.

Palaemonid shrimps; particularly Macrobrachium vollenhovenii (Herklots, 1851) are very abundant in Okumeshi River in Uwkuani Local Government of Delta State, Nigeria. The shrimps serve as a cheap source of animal protein to dwellers in the nearby communities. They also serve as source income for the local fishermen and other buyers from far and near. Their high commercial value is partly due to their relatively large body size [10] and tenacious nature [11]. Sadly, this specie sis highly notorious for accumulation of metals from polluted environments $[10,12]$. This is due to their morphology and niche which maximize accumulation of contaminants from bottom sediments and overlying water [11]. Constant trace metals released into Okumeshi River are 
bound to remain the environmental matrices for long periods [13-15] till they are accumulated in the biota.

The study investigated the transit of trace metals from the environment into $M$. vollenhovenii and ultimately blood of dependent populace, with a view to predicting prognostic hazardous exposures.

\section{MATERIALS AND METHODS}

\subsection{The Study Area}

The Study was conducted on a stretch of Okumeshi River from August, 2016 to January, 2017. The river lies between latitude $5^{\circ} 28^{\prime}-5^{\circ}$ $48^{\prime} \mathrm{N}$ and longitude $5^{\circ} 31^{\prime}-5^{\circ} 40^{\prime} \mathrm{E}$; in Ukwuani Local Government Area of Delta State (Fig. 1). The river serves as source of water, affordable animal protein and means of transportation to the surrounding communities. The river incessantly receives municipal wastes and industrial effluents [16,17]. It is a lotic freshwater with predominant vegetation such as palm trees
(Elaeis guinensis), shrubs, floating Salvinia species, Lemna species and water hyacinth (Eichorrnia crassipes). The study area is located in the Niger Delta area of Nigeria; with sediment which includes Benin, Agbada and Akata formations; ranging from Eocene to Recent age $[18,19]$. The study area is made up of the Benin formation which is of Miocene- recent age. The thickness is about $200 \mathrm{~m}$ [20].

For the purpose of the study water, sediment and M. vollenhovenii samples were collected from four (4) stations which were chosen along the stretch of the river. Station 1 was chosen as the control station. Stations 2 and 3 witnessed varied oil exploration activities over time, while Station 4 was disturbed with agricultural practices and domestic waste deposition. These activities were very severe as at the period of this study. Blood samples were collected from human volunteers who are residents of Ukwuani Local Government and they rely substantially on the supply of Macrobrachium vollenhovenii from the river as cheap source of animal protein. Occupations of the blood donors are basically farming and fishing.

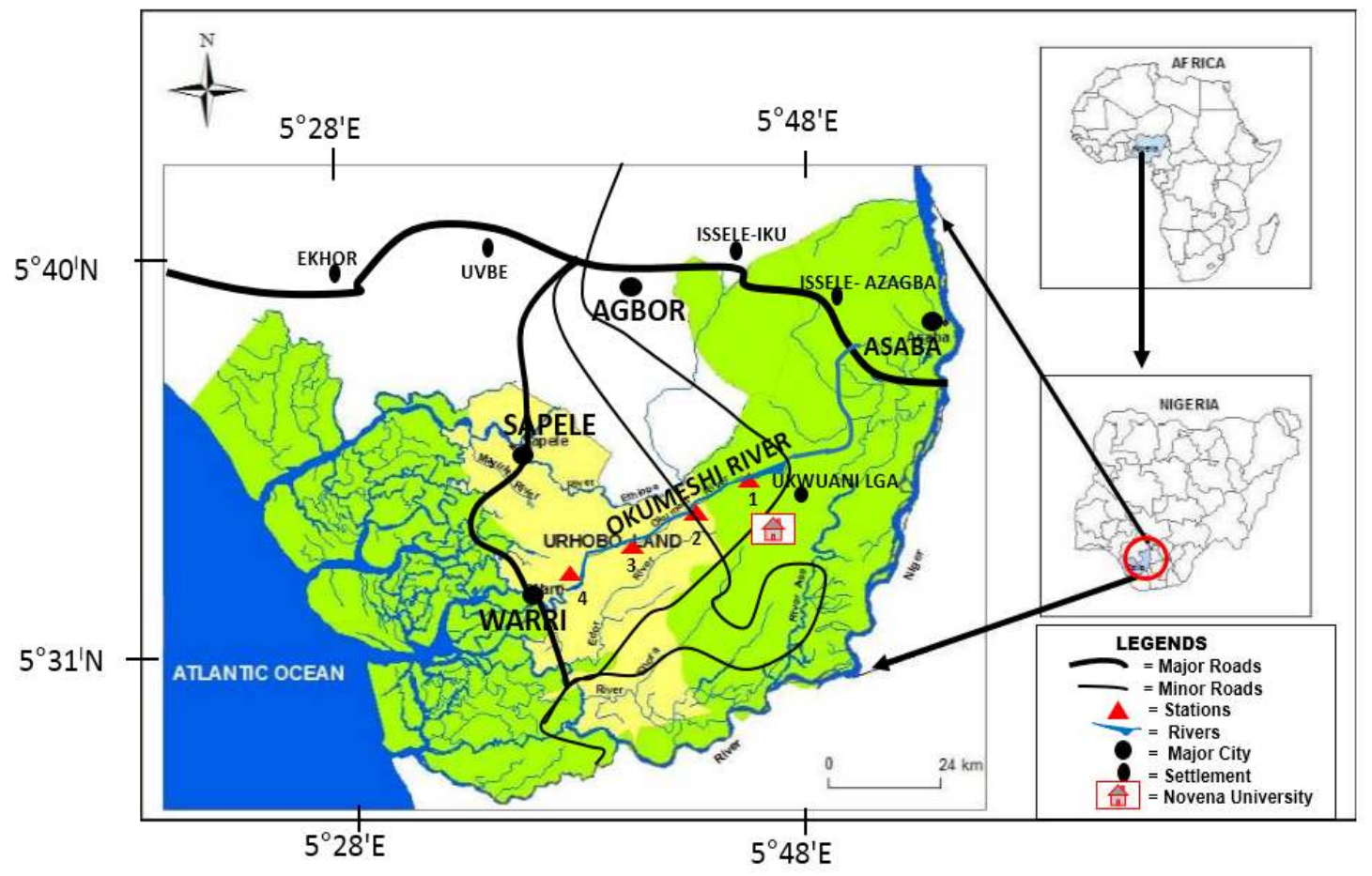

Fig. 1. Map of the study area 


\subsection{Collection and Analysis of Samples}

\subsubsection{Blood samples}

A total of 150 human volunteers $(75$ males and 75 females) were recruited into the research with their informed consent; in line with Helsinki Declaration guidelines. Prior to recruitment it was ascertained that they were all non-smokers. Their general health status was also verified through routine inquiries. The health screening procedures were taken due to the fact that health status influences metal content of the blood [21, 22]. $1 \mathrm{~mL}$ of blood samples was collected from donors in tubes containing lithium heparin anticoagulant; with lid. The tubes and their lids were thoroughly rinsed with de-ionized water and dried prior to use. The collected samples were taken immediately to the laboratory for analysis. Prior to digestion, all samples were vortexed thoroughly to provide a homogeneous matrixfor digestion. Reagent blanks were prepared by addition of deionized water in place of the samples to monitor background concentrations of all analytes. $1 \mathrm{~mL}$ of $2 \mathrm{M}$ analar gradeHNO3 was added to each blood sample and was allowed to react for 30 minutes. Thereafter, $750 \mu \mathrm{L}$ of nonstabilized $30 \% \mathrm{H}_{2} \mathrm{O}_{2}$ solution was added to each sample. Once the addition of all reagents was complete, the tubes were sealed with lids and digested by microwave method using the Discovery SPD (CEM, Matthews, NC). After digestion, the samples were analyzed for trace metals using the Thermo (Bremen, Germany) XSeries 2 Inductively Coupled Plasma Mass Spectrometer (ICP-MS) equipped with a concentric glass nebulizer and peltier-cooled glass spray chamber. At the end of digestion, all samples were removed from the microwave and allowed to cool to room temperature. Samples were stored in a monitored refrigerator at a nominal temperature of $8^{\circ} \mathrm{C}$ until analysis. Trace metal calibration standards for ICP-MS analysis were prepared using $\mathrm{Fe}, \mathrm{Mn}, \mathrm{Zn}, \mathrm{Cu}, \mathrm{Pb}, \mathrm{Cd}$, and $\mathrm{Cr}$ standards. Two sets of calibration standards were prepared for metals that were anticipated to be in low concentrations (such as $\mathrm{Pb}, \mathrm{Cd}, \mathrm{Cr}$, and $\mathrm{Mn}$ ) and high concentrations (such Zn, Cu, and Fe). Samples were analyzed without dilution in the original storage containers to minimize the possibility of contamination. For the calibration, standards back-calculated concentrations were ensured to be within $\pm 15 \%$ of the nominal concentration $( \pm 25 \%$ of the nominal concentration for the lowest concentration standard). Quality control checks was done to ascertain that concentrations for all metals were found to be within $\pm 15 \%$ of the nominal concentration.

\subsubsection{Water samples}

Surface water samples were collected at the four stations on monthly basis using $250 \mathrm{~mL}$ sampling bottles; and transported immediately to the laboratory for analysis of the trace metals. Water samples were pretreated and digested using the wet oxidation method described by Martin et al. [23]. Samples were fixed with $2 \mathrm{~mL}$ nitric acid [23] and then filtered through Whatman filtered paper no 1 and aspirated directly into an Atomic Absorption Spectrometer (Varian Techron Spectr $A A$ - 10; serial number 902 1318) connected to an HP printer (Deskjet 2400 Printer series); for the quantitative determination of all trace metals. The blanks were prepared accordingly. For quality assurance purposes AAS was calibrated for each metal by dissolving 1 gram analar grade metal salt in 1 litre of distilled water. Standard and corresponding blanks were run with each set of experimental digest. The detection limits of iron (0.5 mg/L), manganese $(0.5 \mathrm{mg} / \mathrm{L})$, zinc $(0.5$ $\mathrm{mg} / \mathrm{L})$, copper $(0.05 \mathrm{mg} / \mathrm{L})$, lead $(0.03 \mathrm{mg} / \mathrm{L})$, chromium (0.05 mg/L) and cadmium $(0.01 \mathrm{mg} / \mathrm{L})$ were carefully observed.

To ascertain quality control and standardization measures, all laboratory procedures were repeated at least 3 times and mean values were compared with standard values supplied by FEPA [24].

\subsubsection{Sediment samples}

Bottom sediment samples were collected using a Birge-Ekman grab. The sediment samples were collected in foil papers and wrapped with labelled polythene. All samples were preserved in ice coolers and transported immediately to the laboratory for analysis. This routine was conducted repeated at all stations on monthly basis from August, 2016 to January, 2017.

1 gram air-dry sediment sample was placed in a $300 \mathrm{~mL}$ calibrated digestion tube. $3 \mathrm{~mL}$ concentrated nitric acid (HNO3) was added, swirled carefully and placed in a rack to settle. The mixture was slowly heat up by gradually increasing temperature to about $145^{\circ} \mathrm{C}$ for 1 hour [25]. $4 \mathrm{~mL}$ concentrated Perchloric acid ( $\mathrm{HClO} 4)$ and heat it to $240^{\circ} \mathrm{C}$ for another 1 hour. Mixture was allowed to cool to room temperature. It was filtered through Whatman No. 42 filter paper and the volume was made up to $50 \mathrm{~mL}$ with de- 
ionized water. Heavy metals were then determined by Atomic Absorption Spectrophotometer (model-analyst 200 PerkinEImer).For quality control and standardization measures, all laboratory procedures were repeated at least 3 times and mean values were compared with standard values supplied by FEPA [24].

\subsubsection{Shrimp samples}

A total of 30 representatives [11] of identified Macrobrachium vollenhovenii collected from each station on monthly basis were preserved for laboratory analysis. This was done at low tide regime during night periods using gears such as woven cylindrical non-return valve traps, baskets and scoop nets; in conjunction with coconut, cassava and earthworm baits. Some were procured from fishermen and sources of such samples were properly ascertained before procurement. The samples were preserved in four different coolers with ice; appropriately labeled to indicate the source stations. Whole shrimp was digested according to standard method illustrated by Benhard [26]. 10 grams of wet weight shrimp tissue was placed in silica flasks covered with a glass plate, 20 mLofHNO3: $\mathrm{HClO} 4$ mixture was added; ratio 5:1 respectively. Digestion process was carried out by heating the mixture at $105^{\circ} \mathrm{C}$ for about 24 hours according to the illustrations of Turkmen [27]. The extract was made up to $25 \mathrm{~mL}$ with $\mathrm{HNO} 3(70 \%)$ and diluted with deionized water. For quality assurance, reagent blanks were processed simultaneously in triplicates. Each residue was filtered into volumetric flask with the aid of a Whatman filter paper. The solution was tested for metals concentrations using a Perkin Elmer3110 model Atomic Absorption Spectrophotometer (ASS) and recorded in $\mathrm{mg} / \mathrm{kg}$ wet weight $[11,28]$. The ASS was calibrated for each metal by dissolving 1 gram analar grade metal salt in 1 litre of distilled and deionized water. Standard and corresponding blanks were run with each set of experimental digest. The detection limits of iron (0.05 mg/kg), manganese (0.05 mg/kg), zinc (0.05 mg/kg), copper $(0.005 \mathrm{mg} / \mathrm{kg})$, lead $(0.003$ $\mathrm{mg} / \mathrm{kg})$, cadmium $(0.001 \mathrm{mg} / \mathrm{kg})$ and chromium (0.05 $\mathrm{mg} / \mathrm{kg})$, copper $(0.005 \mathrm{mg} / \mathrm{kg})$ were carefully read.

The actual concentration of trace metals was calculated thus:

Actual concentration of metal $=\mathrm{RD} \times$ Dilution factor [28].

\author{
Where $R D=A S S$ reading of digest \\ Dilution factor $=\frac{\text { Volume of digest used }}{\text { Weight of sample digested }}$
}

\subsection{Statistical Analysis}

The descriptive statistics such as the mean, range and standard error were for significant differences in the heavy metals, nutrients and total hydrocarbons in water and sediment samples was done using ANOVA $(P<0.05)$. Duncan Multiple Range (DMR) test was used to identify the source of variance using SPSS version 19.1.

In order to discern the major parameters of key importance i.e. active components in the matrices, the principal components were analyzed using descriptive statistics such as communalities, total variance, percentage variance and rotated component matrix. Parameters with communality values less than 0.75 were considered insignificant while components with Eigen values less than 1 were also considered insignificant [29]; hence eliminated so that fewer components were further subjected to the Varimax rotation stage using Keiser normalization method [29-31].

Distribution coefficient $(\mathrm{Kd})$ was used to determine the sorption capacity of the parameters into the sediment. Values less than 6 $\mathrm{mg} / \mathrm{L}$ were considered insignificant.

Distribution coefficient;

$$
\log K d=\frac{\log S}{\log W}
$$

Where $\mathrm{S}=$ metals adsorbed into the soil and $\mathrm{W}=$ metal concentration in water.

The Biological Accumulation Factors (BAF) and Biota-Sediment Accumulation Factors (BSAF) of the trace metals in the $M$. vollenhovenii under study were calculated using the following methods;

$$
\mathrm{BAF}=\frac{\mathrm{CF}(\mathrm{mg} / \mathrm{kg})}{\mathrm{CW}(\mathrm{mg} / \mathrm{kg})}
$$

Where BAF is the biological accumulation factor, $\mathrm{CF}$ is concentration of metals in the shrimp and $\mathrm{CW}$ is concentration of metals in water.

$$
\mathrm{BSAF}=\frac{\mathrm{CF}(\mathrm{mg} / \mathrm{kg})}{\mathrm{CS}(\mathrm{mg} / \mathrm{kg})}
$$


Where BSAF is the biota-sediment accumulation factor, CS is the concentration of the metals in sediment and $\mathrm{CW}$ is the in water.

All sample replicates were collected on spatial and temporal basis;

\subsubsection{Spatial replicates}

On monthly basis, the mean concentrations of each metal was calculated thus:

\section{$\mathrm{T} / \mathrm{N}$}

Where

$T=$ Total concentration of metal in all samples.

\subsubsection{Temporal replicates}

This was expressed as the total monthly values divided by number of months. Hence, sample size was expressed as the number of months; which is $\mathrm{N}=6$ in all cases. This was then expressed as Mean \pm Standard Error.

\section{RESULTS}

Concentration of iron observed in water at Station 2 was significantly higher than that of other stations $(P<0.05)$; which exhibited no significant difference (Table 1). However, the levels of iron across all stations were below the recommended limit by FEPA. The levels of manganese detected in the water of Stations 3 and 4 were higher than the regulatory limit, which was higher than the levels obtained at Station 2 and control. Copper concentration in water at Station 4 was higher than the regulatory limit and other stations $(P<0.01)$. Generally, despite the spatial heterogenity in the levels of the trace metals in the water, levels of most of the metals were within regulatory limits throughout the study period.

In the water matrix, only manganese had a significant communality extraction; which was 0.909 (Table 2). Components 1 (4.152) and 2 (1.232) had significant Eigen values and they contributed 51.898 and $15.395 \%$ respectively to the total percentage of variance. Varimax rotated matrix of water (Table 3) showed that manganese $(0.947)>$ copper $(0.883)>$ zinc $(0.817)>$ chromium $(0.759)>\mathrm{Pb}(0.790)$ was the sequence of trace metal activity in component 1 . While $\mathrm{Cd}(0.782)$ and $\mathrm{Fe}(0.812)$ were the only active metals in component 2 .

The mean concentration of $\mathrm{Fe}$ in sediment at Station 2 was significantly higher than Station $3>$ Station $4>$ Station $1(P<0.05)$. Concentrations

Table 1. Summary of heavy metals $(\mathrm{mg} / \mathrm{L})$ in water of Okumeshi River

\begin{tabular}{|c|c|c|c|c|c|c|}
\hline Metals & $\begin{array}{l}\text { Station } 1 \\
\text { Mean } \pm S . E \text { (Range) }\end{array}$ & $\begin{array}{l}\text { Station } 2 \\
\text { Mean } \pm S . E \text { (Range) }\end{array}$ & $\begin{array}{l}\text { Station } 3 \\
\text { Mean } \pm S . E \text { (Range) }\end{array}$ & $\begin{array}{l}\text { Station } 4 \\
\text { Mean } \pm \text { S.E (Range) }\end{array}$ & P value & $\begin{array}{l}\text { FEPA } \\
\text { [24] }\end{array}$ \\
\hline$\overline{\mathrm{Fe}}$ & $1.81 \pm 0.16^{B}(0-2.4)$ & $4.71 \pm 0.25^{\mathrm{A}}(0-3.5)$ & $1.50 \pm 0.19^{B}(0-2.9)$ & $1.48 \pm 0.27^{8}(0.2-5.4)$ & $\mathrm{P}<0.05$ & 20 \\
\hline $\mathrm{Mn}$ & $0.31 \pm 0.01^{\mathrm{B}}(0-0.1)$ & $0.26 \pm 0.06^{\mathrm{B}}(0-0.7)$ & $0.97 \pm 0.22^{A}(0-2.3)$ & $1.26 \pm 0.34^{A}(0-3.7)$ & $P<0.001$ & 0.5 \\
\hline $\mathrm{Zn}$ & $0.7 \pm 0.03^{B}(0-0.4)$ & $0.59 \pm 0.15^{A}(0.1-2.6)$ & $0.92 \pm 0.3^{A}(0.2-5.2)$ & $0.985 \pm 0.25^{A}(0-3.3)$ & $P<0.05$ & 1 \\
\hline $\mathrm{Pb}$ & $0.1 \pm 0.003(0-0.1)$ & $0.08 \pm 0.01(0-0.2)$ & $0.03 \pm 0.24(0-2.7)$ & $0.33 \pm 0.26(0-2.7)$ & $P>0.05$ & $<1$ \\
\hline $\mathrm{Cu}$ & $0.3 \pm 0.01^{\mathrm{l}}(0-0.1)$ & $0.14 \pm 0.03^{b}(0-0.5)$ & $0.13 \pm 0.02^{b}(0-0.4)$ & $1.05 \pm 0.26^{A}(0-2.76)$ & $P<0.01$ & $<1$ \\
\hline $\mathrm{Cd}$ & $0.5 \pm 0.03^{\mathrm{b}}(0-0.4)$ & $0.08 \pm 0.02^{b}(0-0.3)$ & $0.23 \pm 0.12^{\mathrm{b}}(0-1.6)$ & $0.4 \pm 0.16^{A}(0-0.7)$ & $P<0.01$ & $<1$ \\
\hline $\mathrm{Cr}$ & $0.02 \pm 0.01^{c}(0-0.2)$ & $0.35 \pm 0.01^{\mathrm{B}}(0-1.1)$ & $0.71 \pm 0.18^{A}(0-2.1)$ & $0.73 \pm 0.2^{A}(0-2.3)$ & $P<0.01$ & $<1$ \\
\hline
\end{tabular}

Table 2. Principal components of water

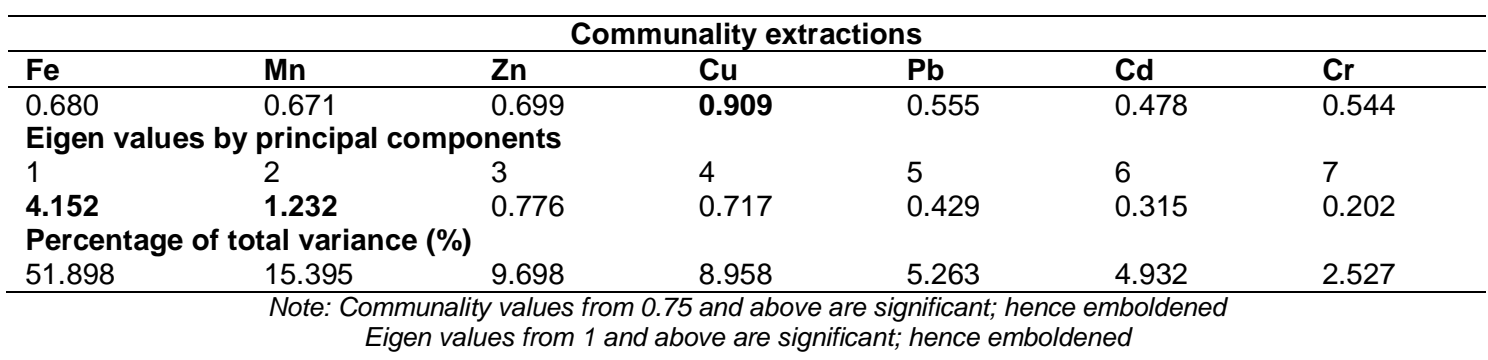


Table 3. Varimax rotated component matrix of water

\begin{tabular}{llllllll}
\hline Component & Mn & $\mathbf{C u}$ & $\mathbf{Z n}$ & $\mathbf{C r}$ & $\mathbf{P b}$ & $\mathbf{C d}$ & $\mathbf{F e}$ \\
\hline 1 & $\mathbf{0 . 9 4 7}$ & $\mathbf{0 . 8 8 3}$ & $\mathbf{0 . 8 1 7}$ & $\mathbf{0 . 7 5 9}$ & $\mathbf{0 . 7 9 0}$ & 0.675 & 0.144 \\
2 & 0.112 & 0.054 & 0.061 & 0.318 & 0.070 & $\mathbf{0 . 7 8 2}$ & $\mathbf{0 . 8 1 2}$ \\
\hline
\end{tabular}

of all trace metals (except lead) in the sediment at all stations; except control exceeded the regulatory limit. The trend of manganese was Stations 2 and $3>$ Station $4>$ Station $1(P<$ 0.001).

Iron (0.784), manganese (0.745), copper (0.802), and cadmium (0.778) had significant communality extractions in the sediment. While only components 1 (3.954), 2 (1.373) and 3 (1.287) were of significant Eigen values (Table 5), and they constituted 49.426, 19.166 and $15.09 \%$ respectively of the total variance. After subjecting only the significant components to further rotation to generate the rotated component matrix; copper (0.896)> cadmium (0.755) > Cr (0.756) was the sequence observed in component 1 (Table 6). The sequence in component 2 was: $\mathrm{Mn}(0.871)>\mathrm{Pb}(0.787)>\mathrm{Zn}$ $(0.771)$. Fe (0.812) was the only active metal in component 3.

Iron (3.28), manganese (6), copper (28.83), cadmium (12.35) and chromium (7.38) had significant sorption into the bottom sediment from the water medium (Table 7) i.e. their sorption capacities are above the significant level of $6 \mathrm{mg} / \mathrm{L}$. Copper had an outstandingly high sorption into the bottom sediment: $\mathrm{Cu}>\mathrm{Cd}>\mathrm{Cr}>$ $\mathrm{Mn}$.

Table 4. Summary of heavy metals $(\mathrm{mg} / \mathrm{kg})$ in sediment of Okumeshi River

\begin{tabular}{|c|c|c|c|c|c|c|}
\hline Metals & $\begin{array}{l}\text { Station } 1 \\
\text { Mean } \pm S . E \text { (Range) }\end{array}$ & $\begin{array}{l}\text { Station } 2 \\
\text { Mean } \pm S . E \text { (Range) }\end{array}$ & $\begin{array}{l}\text { Station } 3 \\
\text { Mean } \pm S . E \text { (Range) }\end{array}$ & $\begin{array}{l}\text { Station } 4 \\
\text { Mean } \pm \text { S.E (Range) }\end{array}$ & $P$ value & $\begin{array}{l}\text { FEPA } \\
{[24]}\end{array}$ \\
\hline$\overline{\mathrm{Fe}}$ & $0.03 \pm 0.06^{\mathrm{D}}(0-2.4)$ & $10.9 \pm 2.2^{A}(9-63.8)$ & $8.44 \pm 0.19^{\mathrm{B}}(0-2.9)$ & $2.38 \pm 0.27^{\mathrm{C}}(0.2-5.4)$ & $P<0.05$ & $\frac{[2+]}{1}$ \\
\hline $\mathrm{Mn}$ & $0.01 \pm 0.003^{C}(0-0.1)$ & $8.24 \pm 0.6^{A}(2-10.7)$ & $5.97 \pm 0.22^{A}(1.2-8.3)$ & $4.26 \pm 0.34^{\mathrm{B}}(0-3.7)$ & $P<0.001$ & 0.4 \\
\hline $\mathrm{Zn}$ & $0.35 \pm 0.06^{\mathrm{V}}(0-0.4)$ & $7.59 \pm 0.15^{\AA}(0.1-2.6)$ & $4.92 \pm 0.3^{\mathrm{B}}(0.2-5.2)$ & $1.99 \pm 0.25^{C}(0-3.3)$ & $P<0.05$ & 3 \\
\hline $\mathrm{Pb}$ & $0.01 \pm 0.001(0-0.1)$ & $0.04 \pm 0.01(0-0.2)$ & $0.03 \pm 0.24(0-2.7)$ & $0.03 \pm 0.26(0-2.7)$ & $P>0.05$ & 0.05 \\
\hline $\mathrm{Cu}$ & $0.05 \pm 0.015^{C}(0-0.1)$ & $14.1 \pm 0.3^{\mathrm{B}}(6.3-22.2)$ & $21.11 \pm 2^{A}(8.2-31.6)$ & $12.01 \pm 2^{\mathrm{B}}(3.4-22.7)$ & $P<0.001$ & 0.3 \\
\hline $\mathrm{Cd}$ & $0.01 \pm 0.001^{c}(0-0.3)$ & $7.03 \pm 0.02^{A}(1.2-10.3)$ & $3.13 \pm 0.12^{\mathrm{b}}(0-5.6)$ & $4.8 \pm 0.16^{\mathrm{B}}(0.3-6.7)$ & $P<0.01$ & 0.05 \\
\hline $\mathrm{Cr}$ & $0.01 \pm 0.001^{\cup}(0-0.2)$ & $0.3 \pm 0.01^{c}(0-1.1)$ & $8.33 \pm 0.18^{A}(0-2.1)$ & $4.73 \pm 0.2^{\mathrm{B}}(0-6.3)$ & $P<0.01$ & 2 \\
\hline
\end{tabular}

Table 5. Principal components of sediment

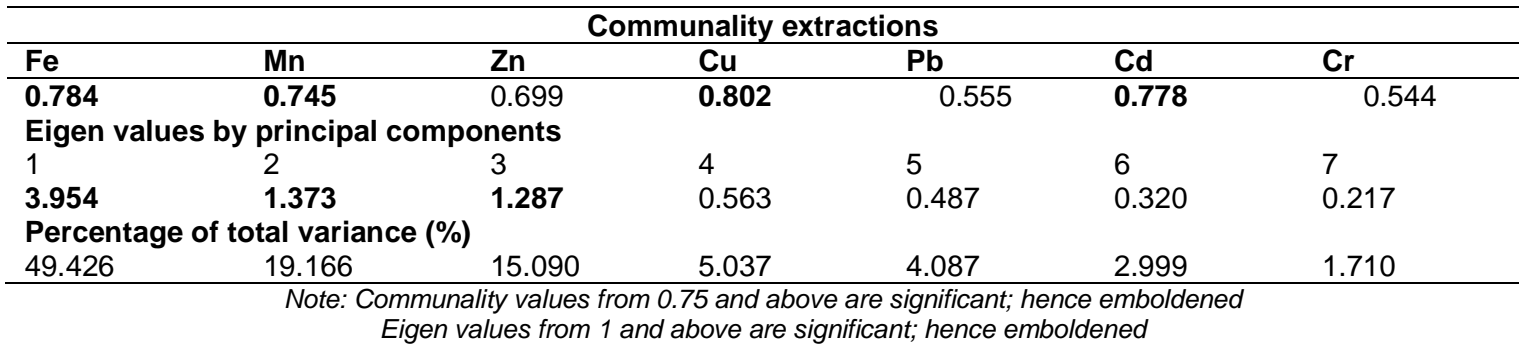

Table 6. Varimax rotated component matrix of sediment

\begin{tabular}{llllllll}
\hline Components & $\mathbf{C u}$ & $\mathbf{C d}$ & $\mathbf{C r}$ & $\mathbf{M n}$ & $\mathbf{P b}$ & $\mathbf{Z n}$ & $\mathbf{F e}$ \\
\hline 1 & $\mathbf{0 . 8 9 6}$ & $\mathbf{0 . 7 5 5}$ & $\mathbf{0 . 7 5 6}$ & 0.687 & 0.656 & -0.136 & 0.401 \\
2 & 0.014 & -0.174 & 0.447 & $\mathbf{0 . 8 7 1}$ & $\mathbf{0 . 7 8 7}$ & $\mathbf{0 . 7 7 1}$ & 0.064 \\
3 & 0.022 & 0.334 & 0.142 & 0.456 & 0.675 & 0.056 & $\mathbf{0 . 8 1 2}$ \\
\hline \multicolumn{7}{c}{ Note: Communality values from 0.75 and above are significant; hence emboldened }
\end{tabular}


Table 7. Distribution coefficients $(\mathrm{Kd})$ of parameters in sediment and water $(\mathrm{mg} / \mathrm{L})$

\begin{tabular}{|c|c|c|c|c|c|c|}
\hline $\mathrm{Fe}$ & Mn & $\mathrm{Zn}$ & $\mathrm{Cu}$ & $\mathbf{P b}$ & Cd & $\mathrm{Cr}$ \\
\hline 3.28 & 6 & 4.65 & 28.83 & 0.244 & 12.35 & 7.38 \\
\hline
\end{tabular}

Generally the levels of most metals observed in the $M$. vollenhovenii at the perturbed sections of the river were distinctively higher than the counterparts at the control station (Table 8). The concentration of iron observed in M. vollenhovenii at Station 2 is significantly higher than that of Station $3>4>$ Station $1(\mathrm{P}<$ 0.01 ). The levels of iron and in the shrimps at all stations exceeded the standard recommendation by FEPA [24]. Most high concentrations of trace metals were detected in shrimps at Stations $2>$ $3>4$. The trend can be attributed to the respective extents of perturbations as observed around the stations. Only manganese, lead and chromium exhibited no significant difference shrimps across the stations. The levels of these trace metals in the shrimps were also below FEPA regulatory limit.

$\mathrm{Fe}$ (0.772), $\mathrm{Mn}$ (0.945), $\mathrm{Cu}$ (0.784) had significant communality extractions (Table 9), while components 1 (4.054), 2 (2.973), 3 (1.887) and 4 (1.563) only had the significant Eigen values; hence were the only considered components. Varimax rotated component matrix showed that $\mathrm{Cu}(0.896)>\mathrm{Fe}(0.725)>\mathrm{Zn}(0.796)>$
$\mathrm{Cd}(0.887)$ were active in component $1 . \mathrm{Cr}$ (0.767) was the active metal in component $2, \mathrm{~Pb}$ (0.783) in component 3 and $\mathrm{Mn} \mathrm{(0.772)}$ in component 4.

As seen in Fig. 2, significant Biological Accumulation Factors (BAF) were observed in iron (3.27), zinc (2.89), copper (17.6) and cadmium (9.17). The BAF of copper in the shrimp was outstandingly higher than others, while manganese, lead and chromium exhibited no significant BAFs. The high BAF of copper in $M$. vollenhovenii can be attributed to its threshold of essentiality in the respiratory pigment of the shrimp.

Significant Biota-Sediment Accumulation Factor (BSAF) was observed only in iron (1). Other trace metals exhibited non-significant BSAF (Fig. 3). This implies that the shrimps accumulated more trace metals from the water matrix than from the sediment matrix.

The levels of zinc (8864.68 \pm 12.72$)$ and copper $(1387.48 \pm 22.21)$ observed in the blood samples of the individuals who consume $M$. vollenhovenii of the river are higher than the recommended ranges; which are 4400-8600 and $800-1300 \mu \mathrm{g} /$ $L$ respectively (Table 11). The levels of other trace metals in the blood samples of the subjects were within the acceptable range recommended by lyengar and Woittiez [33].

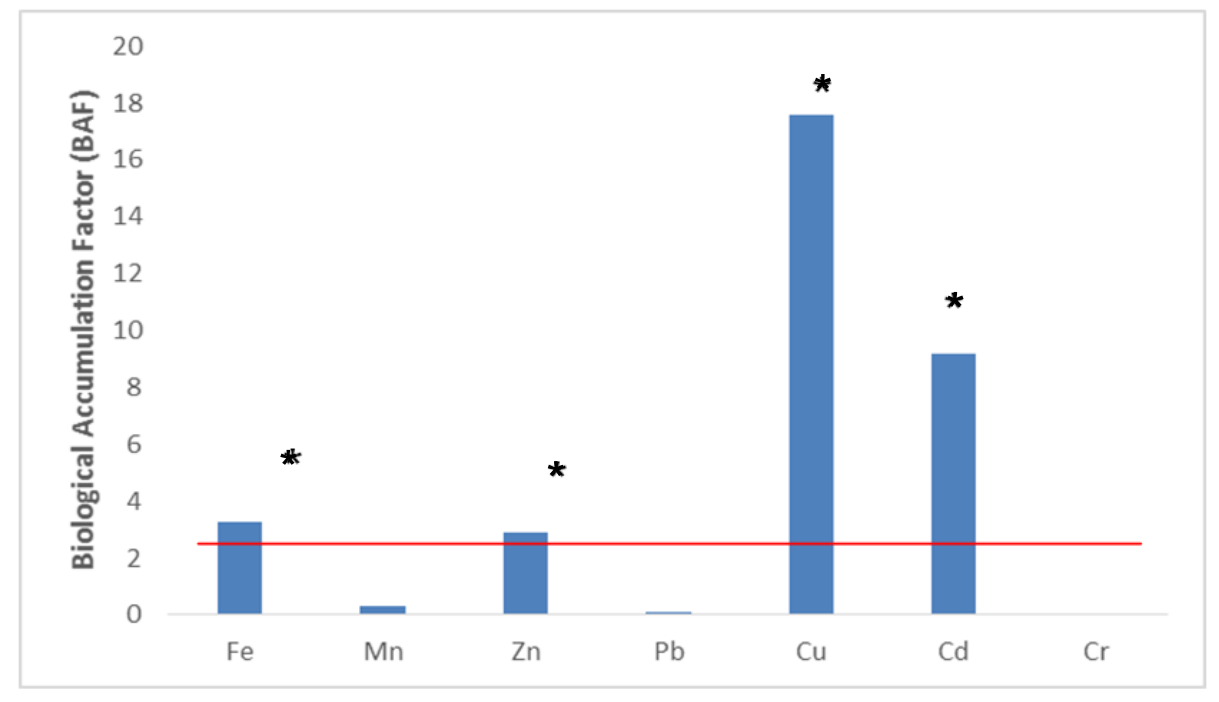

Fig. 2. Biological accumulation factors (BAF) of trace metals in M. vollenhovenii

Note: BAF values of 1 and above signify significant values; indicated by the red line. Asterisked bars indicate trace metals of significant $B A F$ 
Table 8. Summary of trace metals $(\mathrm{mg} / \mathrm{kg})$ in Macrobrachium vollenhovenii of Okumeshi River

\begin{tabular}{|c|c|c|c|c|c|c|}
\hline Parameters & $\begin{array}{l}\text { Station } 1 \\
\text { Mean } \pm S . E \text { (Range) }\end{array}$ & $\begin{array}{l}\text { Station } 2 \\
\text { Mean } \pm S . E \text { (Range) }\end{array}$ & $\begin{array}{l}\text { Station } 3 \\
\text { Mean } \pm S . E \text { (Range) }\end{array}$ & $\begin{array}{l}\text { Station } 4 \\
\text { Mean } \pm S . E \text { (Range) }\end{array}$ & $P$ value & $\begin{array}{l}\text { FEPA } \\
{[24]}\end{array}$ \\
\hline $\mathrm{Fe}$ & $0.3 \pm 0.06^{\mathrm{D}}(0-1.2)$ & $11.2 \pm 2.1^{A}(6.2-16.8)$ & $8.44 \pm 1.19^{B}(2.2-12.9)$ & $1.78 \pm 0.27^{c}(0.2-3.4)$ & $P<0.01$ & 100 \\
\hline $\mathrm{Mn}$ & $0.001 \pm 0.001(0-0.1)$ & $0.23 \pm 0.01(0-0.7)$ & $0.35 \pm 0.01(0-1.1)$ & $0.32 \pm 0.04(0-1.7)$ & $P>0.05$ & 1 \\
\hline $\mathrm{Zn}$ & $0.35 \pm 0.06^{\mathrm{C}}(0-0.84)$ & $4.99 \pm 0.15^{A}(0.1-8.6)$ & $2.92 \pm 0.3^{\mathrm{B}}(0.2-6.9)$ & $0.99 \pm 0.2^{C}(0-1.5)$ & $P<0.05$ & 75 \\
\hline $\mathrm{Pb}$ & ND & $0.01 \pm 0.01(0-0.2)$ & $0.02 \pm 0.24(0-2.7)$ & $0.03 \pm 0.26(0-2.7)$ & $P>0.05$ & 0.05 \\
\hline $\mathrm{Cu}$ & $0.05 \pm 0.015^{\mathrm{C}}(0-0.1)$ & $14.12 \pm 0.01^{A}(0-0.5)$ & $12.3 \pm 0.02^{A}(0-0.4)$ & $2.05 \pm 0.22^{\mathrm{B}}(0-2.76)$ & $P<0.001$ & 3 \\
\hline $\mathrm{Cd}$ & ND $^{c}$ & $6.08 \pm 0.02^{A}(0-0.3)$ & $2.23 \pm 0.12^{b}(0-1.6)$ & $2.8 \pm 0.16^{\mathrm{B}}(0-0.7)$ & $P<0.01$ & 2 \\
\hline $\mathrm{Cr}$ & $0.003 \pm 0.001(0-0.12)$ & $0.04 \pm 0.01(0-0.9)$ & $0.01 \pm 0.002(0-1.2)$ & $0.03 \pm 0.2(0-0.7)$ & $P>0.05$ & - \\
\hline
\end{tabular}
difference, $P<0.01$ means there is much significant difference, and $P<0.001$ means there is very much significant difference. ND $=$ Not Detected. FEPA means Federal Ministry of Environment [24]

Table 9. Principal components of Macrobrachium vollenhovenii

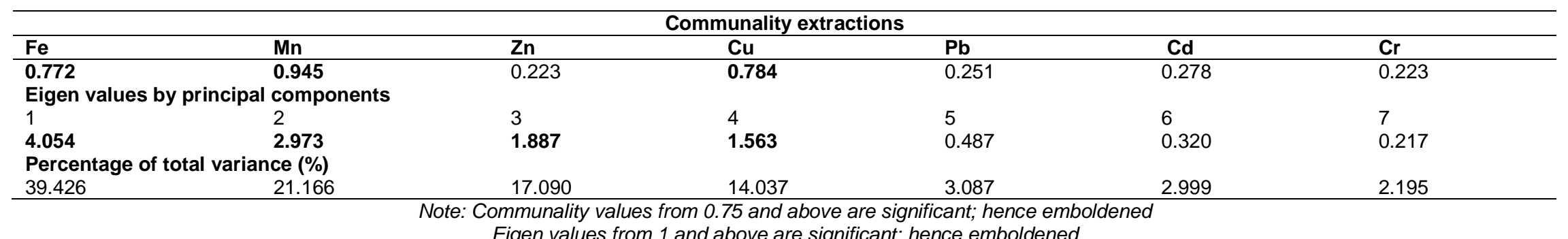

Table 10. Varimax rotated component matrix of Macrobrachium vollenhovenii

\begin{tabular}{|c|c|c|c|c|c|c|c|}
\hline Components & $\mathrm{Cu}$ & $\mathrm{Fe}$ & $Z n$ & Cd & $\mathrm{Cr}$ & Pd & Mn \\
\hline 1 & 0.896 & 0.785 & 0.796 & 0.887 & 0.656 & 0.636 & 0.401 \\
\hline 2 & 0.014 & -0.174 & 0.447 & 0.559 & 0.767 & 0.271 & 0.541 \\
\hline 3 & 0.023 & 0.561 & 0.334 & 0.243 & 0.012 & 0.783 & 0.472 \\
\hline 4 & 0.455 & 0.056 & 0.667 & 0.451 & 0.042 & 0.402 & 0.772 \\
\hline
\end{tabular}

Note: Communality values from 0.75 and above are significant; hence emboldened 


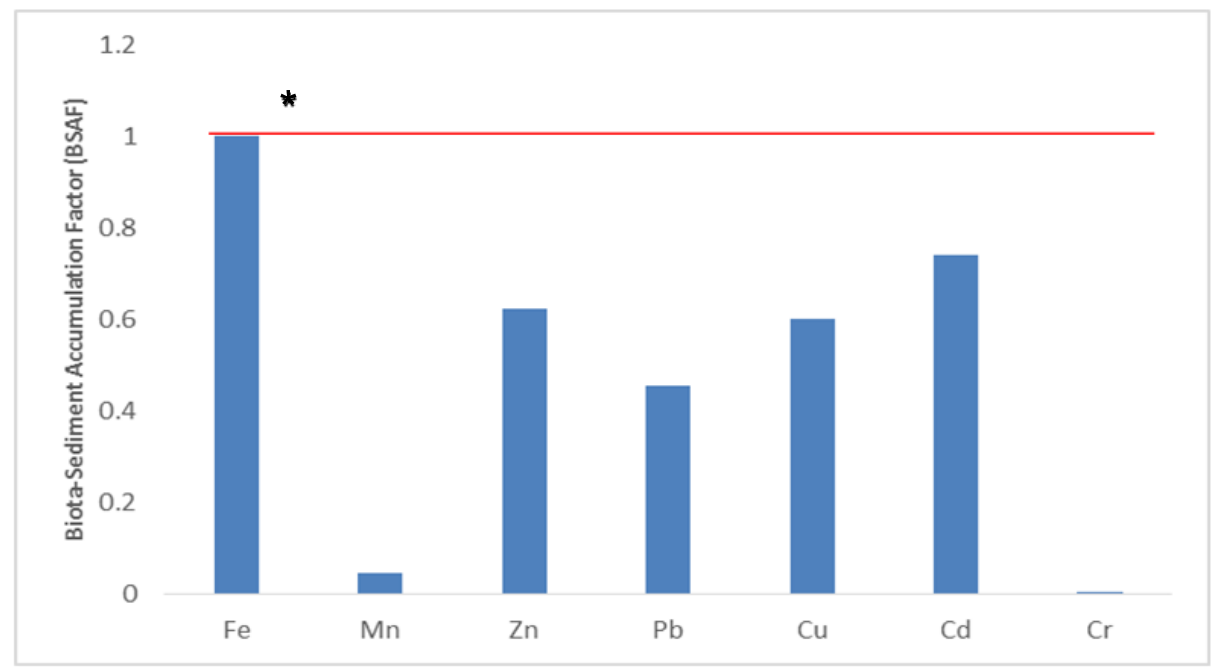

Fig. 3. Biota-sediment accumulation factors (BSAF) of trace metals in M. vollenhovenii Note: BAF values of 1 and above signify significant values; indicated by the red line. Asterisked bars indicate trace metals of significant $B A F$

Result showed that significant concentrations of metals were accumulated only in shrimp samples obtained from the perturbed sections of the river. This necessitated the need to trace these metals in the consumers. Therefore only $M$. vollenhovenii harvested from perturbed sections of the river were further assessed in the study. Significant correlations were observed between the trace metals in the $M$. vollenhovenii tissues and blood samples of subjects (Table 12). Level of iron in the blood samples highly correlated positively (0.81) with that in the M. vollenhovenii tissues. High correlations were also observed between the manganese (0.72) in the blood and that in the shrimp samples; zinc was 0.95, copper was 0.87 and cadmium was 0.67 . Only chromium in the blood and the shrimp showed no significant correlation. The non-essential trace metals in the shrimps correlated negatively with the essential trace metals in the blood samples.

The concentrations of zinc (Fig. 4) and copper (Fig. 5) in the blood of Ukwuani residents were higher than that of control. Zinc and copper concentrations increased with increasing age brackets i.e. (20- 28 years) $<$ (29- 37 years) < (38- 46 years) $<(47-55$ years). This is an indication that the residents of Ukwuani have been exposed to zinc and copper. This also implies that older people are more susceptible to zinc and copper exposure than younger ones. This might be due to dwindling metabolic capacity with age, coupled with higher exposure duration in older individuals.

Table 11. Trace metals in blood samples of Ukwuani residents (August, 2016 to January, 2017); against control and standard ranges

\begin{tabular}{|c|c|c|c|}
\hline Metals & Ukwuani residents & Umelu residents (control) & Certified range [33] \\
\hline & $421.5 \pm 12$ & $311.2 \pm 4.3$ & \\
\hline \multirow[t]{2}{*}{$\mathrm{Fe}$} & (372.4- 493.2) & (172.4- 293.2) & 309- 521 \\
\hline & $11.42 \pm 0.04$ & $10.2 \pm 0.02$ & \\
\hline \multirow[t]{2}{*}{$\mathrm{Mn}$} & $(10.78-12.76)$ & $(9.8-10.6)$ & 8- 18.7 \\
\hline & $8864.68 \pm 122.72^{\pi}$ & $6064.8 \pm 12.2$ & \\
\hline \multirow[t]{2}{*}{$\mathrm{Zn}$} & (2542.3- 14012.2) & $(5842.8-6282.7)$ & $4400-8600$ \\
\hline & $0.031 \pm 0.001$ & $4.8 \pm 0.01$ & \\
\hline \multirow[t]{2}{*}{$\mathrm{Pb}$} & $(0.01-0.05)$ & $(3.01-5.05)$ & 8- 18.7 \\
\hline & $2387.48 \pm 322.21$ & $987.8 \pm 14.22$ & \\
\hline \multirow[t]{2}{*}{$\mathrm{Cu}$} & (252- 4402) & (952- 122.6) & $800-1300$ \\
\hline & $0.9 \pm 0.08$ & $0.59 \pm 0.2$ & \\
\hline \multirow[t]{2}{*}{$\mathrm{Cd}$} & $(0.76-1.42)$ & $(0.23-0.82)$ & $0.3-7$ \\
\hline & $4.21 \pm 0.004$ & $6.2 \pm 0.8$ & \\
\hline $\mathrm{Cr}$ & $(4.14-4.34)$ & $(3.04-8.98)$ & 2.8- 45 \\
\hline
\end{tabular}




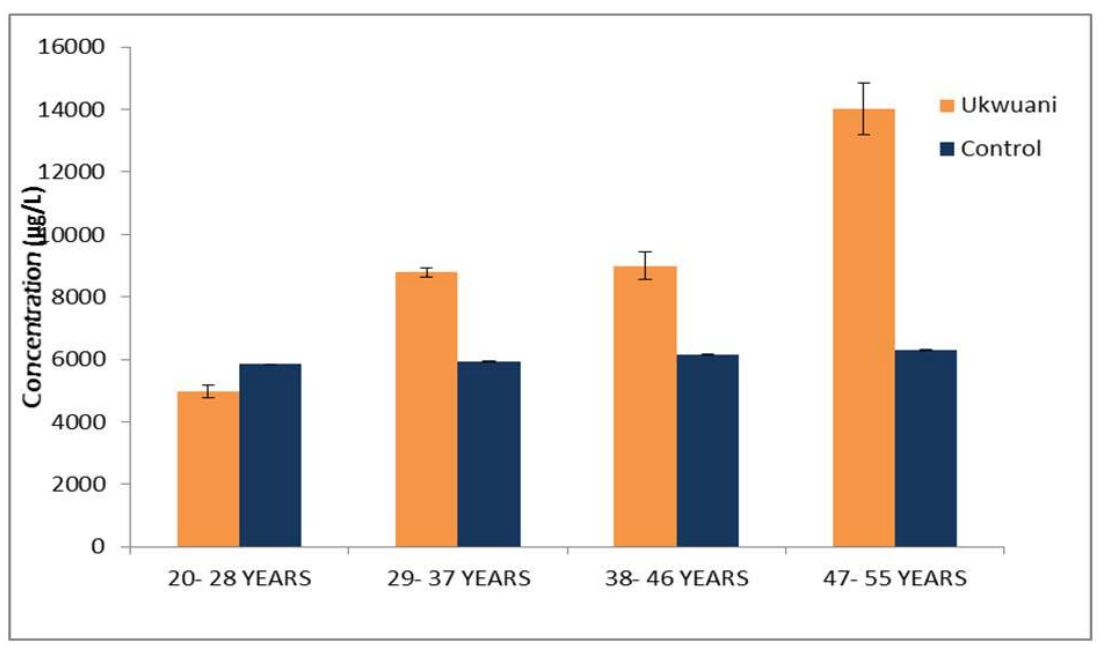

Fig. 4. Concentrations of zinc in different age groups of study area versus control

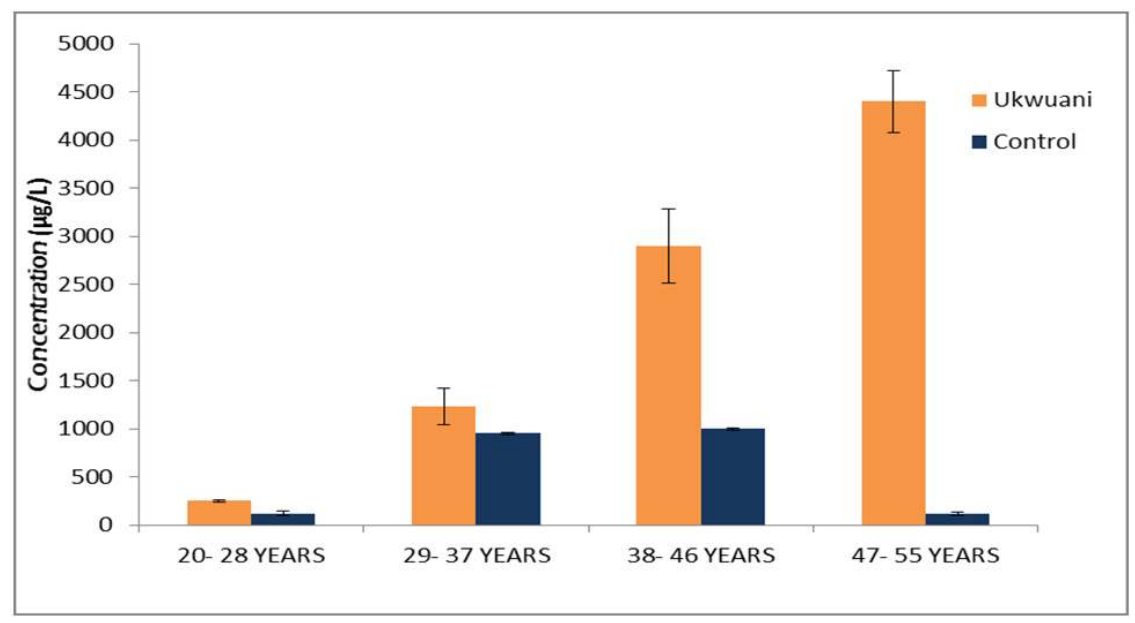

Fig. 5. Concentrations of copper in different age groups of study area versus control

\section{DISCUSSION}

Spatially heterogeneous patterns of the trace metals in the river were apparent. The studied environmental matrices also accumulated the metals at different rates i.e. sediment $>$ M. vollenhovenii > water $>$ human blood. Concentrations of most of the metals analyzed in water of the river were higher at the perturbed stations than the control; although most of them were lower than the regulatory limit, except manganese and copper (Table 1) i.e. concentration of manganese at Stations 3 and 4 were significantly higher than the concentration at the control station and the regulatory standard limit $(\mathrm{P}<0.001)$. While concentration of copper in water at Station 4 was higher than other stations and control $(P<0.01)$. Manganese and copper were also the active components in the water medium (Table 3). Slightly high concentrations of copper and manganese in water at these stations is attributable to oil exploration activities, use of combustion engine boats and saw machines at the saw mill. Although manganese is essential for healthy bones [13]; a constituent of mucopolysaccharides needed for healthy joint formation. Manganese is also essential for regulation of red blood cells and the reproductive cycle in vertebrates generally. It is a constituent of a number of metalloenzymes that occupy key roles in metabolism [34,35]. Due to the high essentiality of manganese, there is little risk of exposure unless at extremely high concentrations; which is not the case in the current study area. High concentration of manganese in water at Gelegele section of Osse River is attributable to oil exploration activities [36,37]. 
Isibor and Imoobe; AJEE, 2(3): 1-16, 2017; Article no.AJEE.31978

Table 12. Correlation of trace metals in $M$. vollenhovenii with the concentrations in human blood samples

\begin{tabular}{|c|c|c|c|c|c|c|c|c|c|c|c|c|c|c|}
\hline $\mathrm{S}-\mathrm{Fe}$ & $\mathrm{S}-\mathrm{Fe}$ & S- Mn & S- Zn & S- $\mathrm{Pb}$ & $\mathrm{S}-\mathrm{Cu}$ & S- Cd & S- Cr & $\mathrm{H}-\mathrm{Fe}$ & H- Mn & $\mathrm{H}-\mathrm{Zn}$ & $\mathrm{H}-\mathrm{Pb}$ & $\mathrm{H}-\mathrm{Cu}$ & $\mathrm{H}-\mathrm{Cd}$ & $\mathrm{H}-\mathrm{Cr}$ \\
\hline & 1 & & & & & & & & & & & & & \\
\hline S- Mn & 0.42 & 1 & & & & & & & & & & & & \\
\hline S- Zn & 0.53 & 0.55 & 1 & & & & & & & & & & & \\
\hline $\mathrm{S}-\mathrm{Pb}$ & 0.02 & -0.02 & 0.01 & 1 & & & & & & & & & & \\
\hline S- Cu & 0.52 & 0.43 & 0.82 & 0.61 & 1 & & & & & & & & & \\
\hline S- Cd & 0.17 & 0.01 & -0.03 & 0.02 & 0.22 & 1 & & & & & & & & \\
\hline S- Cr & 0.31 & 0.34 & 0.58 & 0.04 & 0.44 & -0.67 & 1 & & & & & & & \\
\hline $\mathrm{H}-\mathrm{Fe}$ & 0.81 & 0.52 & 0.04 & 0.22 & 0.47 & 0.41 & 0.33 & 1 & & & & & & \\
\hline $\mathrm{H}-\mathrm{Mn}$ & 0.42 & 0.72 & 0.51 & 0.33 & 0.62 & 0.21 & 0.44 & 0.24 & 1 & & & & & \\
\hline $\mathrm{H}-\mathrm{Zn}$ & 0.02 & 0.29 & 0.95 & 0.44 & 0.02 & 0.34 & 0.71 & 0.47 & 0.76 & 1 & & & & \\
\hline $\mathrm{H}-\mathrm{Pb}$ & 0.33 & 0.21 & -0.75 & 0.29 & 0.02 & 0.07 & 0.09 & 0.02 & -0.78 & 0.44 & 1 & & & \\
\hline $\mathrm{H}-\mathrm{Cu}$ & 0.03 & -0.09 & 0.04 & -0.06 & 0.87 & -0.82 & 0.05 & 0.41 & 0.06 & -0.22 & 0.36 & 1 & & \\
\hline $\mathrm{H}-\mathrm{Cd}$ & 0.45 & 0.27 & 0.07 & 0.41 & 0.06 & 0.67 & 0.22 & 0.12 & 0.04 & -0.01 & -0.27 & 0.46 & 1 & \\
\hline $\mathrm{H}-\mathrm{Cr}$ & 0.04 & 0.08 & 0.49 & 0.06 & 0.02 & 0.33 & 0.35 & 0.24 & 0.17 & 0.02 & -0.71 & -0.66 & 0.19 & 1 \\
\hline
\end{tabular}

Note: Values $\geq 0.5$ signify significant correlations; hence emboldened, $<0.5$ are insignificant. Prefix $S=$ shrimps samples, while Prefix $H=$ Human blood samples 
Concentrations of trace metals were higher in the sediment (Table 2) than the water medium (Table 1) due to the repository nature of the sediment. Through continuous biomagnification, concentrations of copper could rise to attendant levels in organisms at the higher trophic levels and could ultimately culminate in tissue injury in vertebrates; due to its high oxidation potential i.e. excess copper may cause oxidative damage to biological systems, including peroxidation of lipids and other macromolecules.

The journey of the trace metals through all the matrices studied showed that movements of the metals are interactive. The sequence of active components in the water medium was $\mathrm{Mn}>\mathrm{Cu}>$ $\mathrm{Zn}>\mathrm{Cr}>\mathrm{Pb}>\mathrm{Cd}>\mathrm{Fe}$ (Table 3 ), while that of sediment was $\mathrm{Cu}>\mathrm{Cd}>\mathrm{Cr}>\mathrm{Mn}>\mathrm{Pb}>\mathrm{Zn}>$ $\mathrm{Fe}$. This change in trend resulted from the complex interactions among the metals and with the matrices. This is quite evident in their respective sorption capacities which was: $\mathrm{Cu}$ (28.8) > Cd (12.35) > Cr (7.38) > Mn (6). There was a very high correlation between the sorption capacities and the component sequence in the sediment. Very high sorption capacities of copper (141.76) and cadmium (400) were earlier observed at Ikpoba River, Benin City by Ogbeibu et al. [38]. Only sorption capacities of manganese, zinc and lead in the current study area were relatively low compared to the values obtained at Ikpoba River; there is somewhat correlation in the sorption capacities of the rest trace metals. The slight variability between the results obtained from the current study area and that of Ikpoba River can be attributed to the distinguished anthropogenic activities i.e. Ikpoba River was perturbed by effluents from a nearby brewery [38].

The levels of zinc and copper observed in the human blood were higher than the standard limits. This can be attributed to the sequence of components in the shrimps, which was: $\mathrm{Cu}$ $(0.896)>\mathrm{Fe}(0.785)>\mathrm{Zn}(0.796)>\mathrm{Cd}(0.887)>$ $\mathrm{Cr}(0.767)>\mathrm{Pb}$ (0.783), Mn (0.772). The outstanding occurrence of copper in the sampled $M$. vollenhovenii can be attributed to bioavailability of copper in the matrices, particularly water; coupled with the fact that shrimps are notorious accumulators of copper due to the high essentiality of copper in their respiratory pigment haemocyanin [39]. Result indices show that only shrimps at the oil exposed Stations 2 and 3 accumulated copper beyond regulatory limit. This is due to the high bioavailability and affinity for copper (Table 8).
Besides copper the shrimp exhibited affinity in the following order $\mathrm{Cu}>\mathrm{Fe}>\mathrm{Zn}>\mathrm{Cd}>\mathrm{Cr}>\mathrm{Pb}$ $>$ Mn (Table 10). High affinity of $M$. vollenhovenii for these metals necessitates stringent mitigation of the perturbing anthropogenic activities around the river. High bioavailability of the metals to the shrimps is enhanced by its feeding habit and niche i.e. they are detritivorous animals which feed on epibenthic organisms such as polychaetes, molluscs and other crustaceans [40]. Also morphologically, their abdomen not being flexed beneath the thorax maximizes bioaccumulation of contaminants from the sediments and overlying water [10]. However Figures 2 and 3 showed that most of the trace metals were accumulated more from the water than the sediment matrix. Significant bioaccumulation of some trace metals were earlier reported in the $M$. vollenhovenii of Ovia River, Nigeria [37] and Egbokodo River, Nigeria [11].

Zinc and copper were slightly above recommended limits in the human blood (Table 11). Excess zinc in consumers of the $M$. vollenhovenii may cause anaemia, damage to the pancreas and decrease levels of high density lipoprotein cholesterol [41]. While impressible levels of copper observed in the blood of the consumers of $M$. vollenhovenii may elicit liver cirrhosis [42]. These health consequences are liable to ensue of the trend in the aquatic environment is left unmitigated over an appreciable period of time. The high levels of the trace metals in the blood can be traced to their substantial availability in the shrimps. This is also buttressed by the fact very high positive correlations occurred between zinc (0.95) and copper (0.87) in the shrimp and blood samples of the dependent populace (Table 12).

\section{CONCLUSION}

Results showed that Okumeshi River was impacted by the anthropogenic activities which may have some health impacts on the consumers of the Macrobrachium vollenhovenii of the river. High level of zinc and copper in human blood necessitates a prompt bioremediation in the aquatic environment. The observed insalubrity of the shrimps is a prognostic of chronic health hazards to the consumers; which is also a function of the predominant oil exploration activities. Copper had an uninterrupted transit into the blood of the consumers from the aqueous phase. While zinc showed some significant level of 
biomagnification. The study provided an early signal of likely impending catastrophe; necessitating a proactive regulation of trace metals released into the aquatic system through the prevalent anthropogenic activities; mainly oil exploration.

\section{COMPETING INTERESTS}

The study neither contains samples obtained from clinical studies nor personally identifiable patient data. There is stringent anonymity of the volunteers who donated blood in the interest of the benefits the research promises to offer to safeguard public health. The authors hereby declare that no competing interests exist.

\section{REFERENCES}

1. Mansour SA, Sidky MM. Ecotoxicological studies. 3: Heavy metals contaminating water and fish from Fayoum Governorate, Egypt. Food Chem. 2002;78:15-22.

2. Jezierska B, Witeska M. The metal uptake and accumulation in fish living in polluted waters. Twardowska, I. et al. (eds.). Soil and Water Pollution Monitoring, Protection and Remediation. 2006;3(69):107-114.

3. Akintujoye JF, Anumudu $\mathrm{Cl}$, Awobode $\mathrm{HO}$. Assessment of heavy metal residues in water, fish tissue and human blood from Ubeji, Warri, Delta State, Nigeria. J. Appl. SC. Environ. Manage. 2013;17(2):291297.

4. Tukura BW, Gimba CE, Ndukwe IG, Kim BC. Physicochemical characteristics of water and sediment in Mada River, Nasarawa State, Nigeria. International Journal of Environment and Bioenergy. 2012;1(3):170-178.

5. Isibor PO, Imoobe TOT, Izegaegbe JI, Oluowo EF. Assessment of some heavy metals and total hydrocarbons in Clarias gariepinus fish of Osse River, Edo State, Nigeria. J. Environ. Sci., Toxicol. Food Technol. 2016;10(9):144-151.

6. Ogbeibu AE, Oriabure PA, Oboh IP, Edogun IS. The effects of Brewery effluent discharge on the water quality and sediment of Ikpoba River, Benin City, Nigeria. Journal of Aquatic Sciences. 2014; 29(1A):43-58.

7. Froese $\mathrm{KL}$, Verbrugge $\mathrm{DA}$, Ankley $\mathrm{GT}$, Niemi GJ, Larsen CP, Giesy JP. Bioaccumulation of polychlorinated biphenyls from sediments to aquatic insects and tree swallow eggs and nestlings in Saginaw Bay, Michigan, USA. Environmental Toxicology and Chemistry 1998;17(3):484-492.

8. Davies OA, Allison ME, Uyi HS. Bioaccumulation of heavy metals in water, sediment and periwinkle (Tympanotonus fuscatus var radula) from the Elechi Creek, Niger Delta. African Journal of Biotechnology. 2006;5 (10):968-973.

9. Akan JC, Salwa M, Yikala BS, Chellube ZM. Study on the distribution of heavy metals in different tissues of fishes from river Benue in Vinikilang, Adamawa State. British Journal of Applied Science \& Technology. 2012;2(4):311-333.

10. Omoigberale MO, Ikponmwosa-Eweka O. Evaluation of heavy metals of the Palaemonid shrimps (Macrobrachium vollenhovenii) in Osse River, Nigeria. Bioscience Research Communications. 2010;22(5):247-254.

11. Isibor PO, Oluowo FE. Evaluation of Some Heavy Metals and Total Petroleum Hydrocarbon in Water and Palaemonid Shrimps (Macrobrachium vollenhovenii) of Egbokodo River, Warri, Delta State, Nigeria. J. Appl. Life Sci. Int. 2016;4(6):112.

12. Edema U, Egborge ABM. Heavy metal content of Macrobrachium species (Crustacea: Palaemonidae) from Warri River, Nigeria. Tropical Journal of Environment, Science and Health. 1999; 2(1):65-70.

13. Li P, Qian H, Howard KWF, Wu J, Lyu X. Anthropogenic pollution and variability of manganese in alluvial sediments of the Yellow River, Ningxia, northwest China. Environmental Monitoring and Assessment. 2014;186(3):1385-1398.

14. Li P, Qian H, Howard KWF, Wu J. Heavy metal contamination of Yellow River alluvial sediments, northwest China. Environmental Earth Sciences. 2015; 73(7):3403-3415.

15. Li P, Wu J, Qian H, Zhou W. Distribution, enrichment and sources of trace metals in the top soil in the vicinity of a steel wire plant along the Silk Road economic belt, northwest China. Environ Earth Sci. 2016; 75(10):909.

16. Ekeanyanwu $\mathrm{CR}$, Ogbuinyi CA, Etienajirhevwe OF. Trace metals distribution in fish tissues, bottom sediments and water from Okumeshi River in Delta State, Nigeria. Ethiopian Journal of 
Environmental Studies and Management. 2010;3(3):12-17.

17. Ekeanyanwu CR, Ogbuinyi CA, Etienejirhevwe OF. Trace metals distribution in fish tissues, bottom sediments and water of Okumeshi River in Delta State, Nigeria. Environmental Research Journal. 2011;5(1):6-10.

18. Short KC, Stauble AJ. Outline of Geology of Niger Delta. AAPG. Bull. 1967;51:761779 .

19. Asseez LO. Review of the stratigraphy, sedimentation and structure of the Niger Delta. In Geology of Nigeria (C.A. Kogbe, ed.) Elizabethan Publishing Company Lagos, Niger. 1976;428.

20. Kogbe CA, Mehes K, Salam MB. Biostratigraphy of upper cretaceous and tertiary sediment penetrated by Gbekebo "B" well, Niger Delta, Nigeria. In: Geology of Nigeria (C.A. Kogbe, ed.) Elizaberthan Publishing Company, Lagos. 1976;352.

21. Centers for Disease Control and Prevention (CDC). Second nutritional report on biochemical indicators of diet and nutrition in the U.S. population. National Center for Environmental Health. 2012; 483.

22. Harrington JM, Young DJ, Essader AS, Summer SJ, Levine KE. Analysis of human serum and whole blood for mineral content by ICP-MS and ICP-OES: Development of a mineralomics method. Biol. Trace Elem. Res. 2014;160(1):132-142.

23. Martin GR, Smoot JL, White KD. A comparison of surface-grab and crosssectionally integrated stream-water quality sampling methods. Water Environ. Res. 1992;64(7):866-876.

24. Federal Environmental Protection Agency (FEPA). Guidelines and Standards for Environmental pollution control in Nigeria. 2003;420.

25. Estafan J, Somar R, Ryan J. Methods of soil, plant and water analysis: A manual for the West Asia and North Africa Region. International Centre for Agriculture in Dry Areas. 2013;243.

26. Benhard M. Manual of methods in the aquatic environment research. FAO. Fisheries technical paper FIRI/T. Number 158, Food and Agricultural Organization, Rome; 1976.

27. Turkmen G. Seasonal variation in heavy metals in shrimps Penaeus kerathurus (Forskal, 1775) from Izmir Bay. J. Amin. Vet. Adv. 2012;11(15):2839.
28. Olaifa FE, Olaifa AK, Adelaja AA, Owolabi AG. Heavy metal contamination of Clarias gariepinus from lake and fish farm in Ibadan, Nigeria. Afr. J. Biomed. Res. 2004; 7:145-148.

29. Chatfield C, Collin AJ. Introduction to Multivariate Analysis. Biometrical Journal 1980;24(5):436.

DOI: $10.1002 /$ bimj.4710240504

30. Hope K. Methods of multivariate analysis. University of London Press Ltd. St. Paul's House, Warwick Lane, London EC4, SBN 340073314 Unibook;1968.

31. Mazlum S. Variable selection in water quality monitoring networks. Master of Science Thesis Submitted in Partial Fulllment of the Requirements for the Degree of Master of Science in Environmental Engineering. DokuzEylul University, Graduate School of Natural and Applied Sciences; 1992.

32. Soares MR, Alleoni LRF. Distribution coefficient (KD) of heavy metals in Brazillian soils. 18tth World Congress of Soil Sciences, Philadelphia, USA. 2006; 134.

33. lyengar V, Woittiez J. Trace elements in human clinical specimens: Evaluation of literature data to identify reference values. Clin Chem. 1988;34(3):474-481.

34. Woolhouse HW. Toxicity and tolerance in the responses of plants to metals. In: Lange OC, Nobel PS, Osmond CB, Ziegler $\mathrm{H}$, eds. Encyclopedia of plant physiology II. New York, NY, Springer-Verlag. 1983;300.

35. Burnell JN. The biochemistry of manganese in plants. In: Graham RD, Hannam RJ, Uren NC, eds. Manganese in soils and plants. Dordrecht, Kluwer Publishers. 1988;408.

36. Omoigberale $\mathrm{MO}$, Ogbeibu $\mathrm{AE}$. Environmental impacts of oil Exploration and Production on the Macrobenthic Invertebrate Fauna of Osse River, Southern Nigeria. Res. J. Environ. Sci. 2010;4:101-114.

37. Oguzie FA, Ehigiator FAR. Concentration of heavy metals in three African prawn (Crustacea: Palaemonidae) from Osse River in Edo State, Nigeria. J. Agric. Sc. Env. 2011;11(1):104-113.

38. Ogbeibu AE, Oriabure PA, Oboh IP, Edogun IS. The effects of Brewery effluent discharge on the water quality and sediment of Ikpoba River, Benin City, Nigeria. Journal of Aquatic Sciences. 2014; 29(1A):43-58. 
39. Van de Broek WLF. Seasonal levels of chlorinated hydrocarbons and heavy metals in fish and brown shrimps from the Medway Estuary Kent. Environmental Pollution. 1979;19:21-28.

40. Isibor PO. The abiotic ecology and prevalence of palaemonid shrimps (Crustacea: Palaemonidae) of Osse River, Edo State, Nigeria. Journal of Life Sciences International. 2016;9(3):1-11.

DOI: 10.9734/JALSI/2016/29497
41. Agency for Toxic Substances and Disease Registry (ATSDR). Public Health statement for zinc: Public service. Department of Health and Human Services. 2005;42.

42. Agency for Toxic Substances and Disease Registry (ATSDR). Toxicological profile for polyaromatic hydrocarbons $(\mathrm{PAH})$ in Goldstein, B.D. et al., 2011. The Gulf Oil Spill. New England Journal of Medicine. 2010;364(14):1334-1348.

(c) 2017 Isibor and Imoobe; This is an Open Access article distributed under the terms of the Creative Commons Attribution License (http://creativecommons.org/licenses/by/4.0), which permits unrestricted use, distribution, and reproduction in any medium, provided the original work is properly cited.

Peer-review history:

The peer review history for this paper can be accessed here: http://sciencedomain.org/review-history/18663 